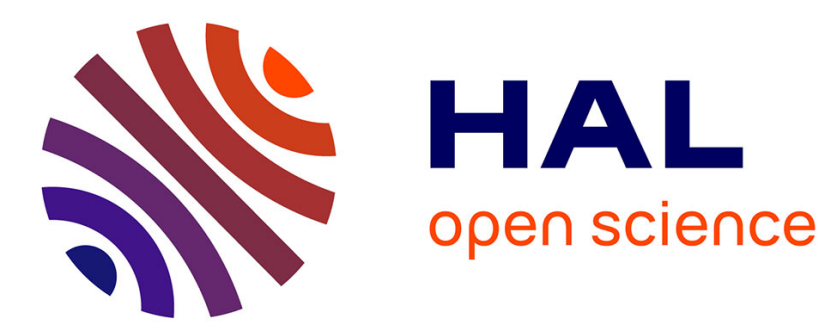

\title{
Resistance of European winter wheat germplasm to leaf rust
}

\author{
Michael Winzeler, Ákos Mesterházy, Robert Park
}

\section{To cite this version:}

Michael Winzeler, Ákos Mesterházy, Robert Park. Resistance of European winter wheat germplasm to leaf rust. Agronomie, 2000, 20 (7), pp.783-792. 10.1051/agro:2000175 . hal-00886082

\section{HAL Id: hal-00886082 \\ https://hal.science/hal-00886082}

Submitted on 1 Jan 2000

HAL is a multi-disciplinary open access archive for the deposit and dissemination of scientific research documents, whether they are published or not. The documents may come from teaching and research institutions in France or abroad, or from public or private research centers.
L'archive ouverte pluridisciplinaire HAL, est destinée au dépôt et à la diffusion de documents scientifiques de niveau recherche, publiés ou non, émanant des établissements d'enseignement et de recherche français ou étrangers, des laboratoires publics ou privés. 


\title{
Original article
}

\section{Resistance of European winter wheat germplasm to leaf rust}

\author{
Michael Winzeler ${ }^{a *}$, Ákos MesterhÁzY ${ }^{\mathrm{b}}$, Robert F. PARK ${ }^{\mathrm{c}}$, \\ Pavel BarTos**, Maria Csösz**, Henriette GoYeAU**, Mariana ITtU**, Elwyn Jones**, \\ Franziska LösChENBERGER**, Klara MANNINGER**, Marina PASQUINI**, Klaus RICHTER**, \\ Diego Rubiales**, Gabriele SchaChERMAYR**, Anna StRZEMBICKA**, \\ Maxime Trottet**, Otto Unger**, Gyula VidA**, Ursula Walther** \\ ${ }^{a}$ Swiss Federal Research Station for Agroecology and Agriculture, FAL-Reckenholz, 8046 Zürich, Switzerland \\ ${ }^{\mathrm{b}}$ Cereal Research Non-profit Co., PO Box 391, 6701 Szeged, Hungary \\ ${ }^{c}$ Plant Breeding Institute, University of Sydney, 2570 Camden NSW, Australia
}

(Received 12 April 2000; revised 4 August 2000; accepted 10 August 2000)

\begin{abstract}
Seventy two wheat cultivars and breeding lines were tested for at least two years in up to ten European countries for resistance against leaf rust under field conditions. In addition, seedling resistance was determined with local races and with defined isolates to postulate resistance genes. Nine entries (Batis, Capo, RE9001, RE9801, Terza, Toronit, Titlis, Barra, Beaufort) were highly resistant at all locations, and were regarded as excellent sources of resistance for breeding programs. Two thirds of the 72 entries possess adult plant and/or partial resistance. Cultivars with the gene $\operatorname{Lr} 13$ differed greatly in disease response showing that $\operatorname{Lrl3}$ alone does not provide adequate resistance in Europe. Gene $\operatorname{Lr} 37$ provided generally good adult plant resistance but seedlings with this gene were moderately susceptible. Many of the wheat cultivars/lines investigated possess unidentified adult plant resistance gene(s). Seedling resistance was attributable mostly to the genes Lr1, Lr3a, Lr3ka, Lr10, Lr14a, Lr17b, Lr20 or Lr26.
\end{abstract}

Triticum aestivum / Puccinia recondita / wheat / leaf rust / resistance

Résumé - Résistance du germplasme de blé d'hiver européen à la rouille des feuilles. Pendant au moins deux ans, 72 cultivars et lignées de sélection avancées de blé ont été testées aux champs dans dix pays européens pour évaluer la résistance à la rouille des feuilles. De plus, la résistance a été évaluée lors d'essais en laboratoire sur des plantules infec-

Communicated by Rients E. Niks (Wageningen, The Netherlands)

* Correspondence and reprints michael.winzeler@fal.admin.ch

** Affiliations are in Appendix 
tées avec des isolats de formules virulence/avirulence connues pour postuler des gènes de résistance. Neuf d'entre elles (Batis, Capo, RE9001, RE 9801, Terza, Toronit, Titlis, Barra, Beaufort) ont montré une très forte résistance sur tous les sites et ont été considérées comme des sources de résistance excellentes pour les programmes de sélection. Deux tiers des 72 entrées possédaient une résistance à l'état adulte et/ou une résistance partielle. Les cultivars contenant le gène Lr13 ont montré des réactions très différentes à la maladie; il semble donc que le gène $\operatorname{Lr} 13$ seul ne procure pas une résistance d'un niveau suffisant en Europe. Le gène Lr37 a permis une bonne résistance des plantes au stade adulte tandis qu'au stade plantule une sensibilité moyenne a été observée. Un grand nombre des cultivars de blé analysés possède des gènes de résistance encore inconnus qui sont exprimés au stade adulte. La résistance au stade plantule a été attribuée principalement aux gènes Lrl, Lr3a, Lr3ka, Lr10, Lr14a, Lr17b, Lr20 ou Lr26.

Triticum aestivum / Puccinia recondita / blé tendre / rouille des feuilles / résistance

\section{Introduction}

Leaf rust, caused by Puccinia recondita f. sp. tritici (Prt), is one of the major diseases of wheat (Triticum aestivum L.) in Europe. Although it does not cause severe epidemics in the continent every year, the disease reaches epidemic levels in several areas every year and causes severe losses. Severe epidemics were recorded recently in Switzerland, Hungary, Germany, Romania, and regions of France and Italy.

Breeding wheat cultivars with resistance to leaf rust is the most effective and environmentally sound approach to prevent yield losses. Up to now more than 40 leaf rust resistance genes have been characterized [7]. Most of these genes are expressed throughout the whole life of the plant (seedling resistance), however some are expressed at adult plant growth stages only (adult plant resistance; APR). Adult plant resistance to leaf rust in wheat can be under oligogenic or polygenic control. Examples are known in which APR is governed by single genes which confer hypersensitivity (e.g. $L r 12, L r 13, L r 22 b$ ), and many of these have been overcome by the development of corresponding virulence in the pathogen [11]. In contrast, the gene Lr34 confers partial resistance to leaf rust and has proven durable [15]. Partial resistance is a form of moderate resistance in which a hypersensitive reaction does not occur $[14,16]$. Promising ways to achieve durable resistance include pyramiding race-specific resistance genes, combining seedling resistance and APR genes, and combining effective race-specific genes with high levels of partial resistance.

Knowledge of pathogenic variability in the pathogen population is an important prerequisite for resistance breeding. European surveys of virulence in Prt have been carried out for decades in many countries, to monitor changes in the race composition. Initial data on the pathogenicity of Prt, across Europe, with respect to seedling resistance genes, are now available $[8,10]$.

Preliminary studies have indicated that many European wheats possess additional APR. In a study at the Swiss Federal Research Station for Agroecology and Agriculture Zürich-Reckenholz carried out between 1988 and 1994, the occurrence of APR was examined in 250 European winter wheat varieties and breeding lines by comparing seedling and adult plant responses [19]. This study showed that $86 \%$ of the entries had a component of APR to leaf rust. Gaining a better understanding of these APRs will be important for future attempts to achieve durable resistance to leaf rust, and in maintaining diversity in the resistances deployed by European breeding programs.

The present paper reports on a coordinated European study to determine the resistance to leaf rust in wheat cultivars and advanced breeding lines known to possess some resistance to local populations of Prt. The postulation of seedling resistance genes was an important prerequisite in allowing an estimate of the level of APR and/or partial resistance for each genotype. Together with the virulence surveys, the nursery data identified 
resistances that were effective across Europe. The nursery also identified current wheat genotypes with different types of resistance (seedling, adult, partial) that were widely effective in Europe. These genotypes should be useful as donors of resistance.

\section{Materials and methods}

\subsection{Plant material}

The multilocation test was conducted over four years, from 1996 to 1999. Each participant selected cultivars or breeding lines for inclusion in the test. The cultivars selected were regarded as possessing some resistance to leaf rust, and as such did not represent the average level of resistance in participating breeding programs. The experiments were coordinated by the Swiss Federal Research Station for Agroecology and Agriculture FALReckenholz (Winzeler), where seed was collected and redistributed, and data were collated and analyzed.

The number of entries increased from year to year $(1996,25 ; 1997,52 ; 1998,69 ; 1999,86$ entries) because of increases in the number of participants and in the number of entries per participant. In total 103 entries were tested between 1996 and 1999, including one susceptible standard. Thirty one cultivars were tested for one year only and were therefore not considered in the analysis of the data. Thirty one, twenty five and sixteen cultivars were tested for two, three and four years, respectively.

\subsection{Field tests}

The number of field tests varied from year to year: in 1996, there were nine field tests in six countries (D, I, UK, CZ, CH, H); in 1997, ten field tests in eight countries (F, D, UK, I, CH, P, CZ, H); in 1998, 14 field tests in 9 countries (F, D, UK, I, $\mathrm{CH}, \mathrm{P}, \mathrm{A}, \mathrm{CZ}, \mathrm{H}$ ); and in 1999, 13 field tests in 10 countries (F, D, UK, I, CH, P, CZ, H, E, RO). The methods used to test entries for leaf rust resistance differed between collaborators. All experiments were sown in fall, and entries were grown as single rows or micro-plots with one to four replications. In most cases, plots were infected by naturally occurring inoculum and no effort was made to identify the pathotypes present. Where artificial inoculations were performed, only local races that represented the population of the respective country were used. Leaf rust was recorded one to several times, using either a 1 to 9 scale $(1=$ no symptoms, 9 = fully diseased) or a modified Cobb's Scale (\% diseased leaf area and disease response). To make data comparable, the coordinator (Winzeler, FAL-Reckenholz) rated the entries, according to their scores and the score of the susceptible check, as resistant (R), moderately resistant (MR), moderately susceptible (MS) and susceptible (S). The resistance level of the entries was evaluated on the basis of the number of ratings in the four classes of reactions.

\subsection{Seedling tests}

As with field tests, the number of seedling tests varied from year to year: in 1996, there were 15 seedling tests in five countries $(\mathrm{D}, \mathrm{I}, \mathrm{CZ}, \mathrm{CH}, \mathrm{H})$; in 1997, 23 seedling tests in four countries (D, I, P, CZ); in 1998, 27 seedling tests in five countries (D, I, UK, P, CZ); and in 1999, 36 seedling tests in 5 countries (D, UK, $\mathrm{P}, \mathrm{CZ}, \mathrm{H})$. The methods used to determine seedling disease response varied between collaborators. Isolates or isolate mixtures that were representative of the leaf rust population of the respective countries were used. Scoring was done either by a 1 to 8 scale $(1=$ completely resistant, $5=$ intermediate or heterogeneous response, $8=$ completely diseased) or according to the scale of Stakman et al. [18]. To make results comparable, the coordinator grouped the results into three levels: resistant, intermediate (heterogeneous or intermediate response) and susceptible. For entries that were resistant in more than $75 \%$ of the seedling tests we assume that seedling genes are predominantly responsible for the expression of resistance in the field. Entries which were susceptible in at least $80 \%$ of tests, but which displayed resistance in field tests, were classified as possessing APR. 


\subsection{Determination of resistance genes}

Additional seedling tests were conducted at the Plant Breeding Institute Cobbitty (Park). These tests examined all entries in the 1997 and 1999 nurseries. Postulation of seedling resistance genes was accomplished by testing nursery entries with an array of pathotypes of known contrasting pathogenicities (Tab. I). The methods used to raise and inoculate seedlings followed those outlined by Park et al. [13]. A set of additional genotypes, comprising key differentials, was included for each test to ensure purity and correct identity of the isolates used, and also to permit comparisons between the phenotypes observed with those produced by known resistance genes. In several cases results for individual genotypes included in both nurseries differed, and in these cases, the results of the 1999 nursery are presented.

\section{Results and discussion}

A total of 72 genotypes were tested over the four year period (Tab. II), providing an extensive set of data concerning the response of the entries in different environments. This permitted some general conclusions to be made in relation to the diversity and nature of resistance in the wheats tested.

\subsection{Field tests in Europe}

The entries were tested in 16 to 44 different environments across Europe during two to four years. One environment is defined as one location per year. According to the number of ratings in the four classes of reactions (R, MR, MS and S) the entries were assigned to six groups (Tab. II). Group I consisted of the most resistant cultivars/lines and included Batis, Capo, RE9001, RE9801, Terza, Toronit, Titlis, Barra and Beaufort. These entries displayed a resistant or moderately resistant reaction in all tests, indicating that the high level of resistance of these entries was effective across Europe. These cultivars are therefore excellent sources of resistance for use in breeding programs, particularly as the resistance is already present in an adapted and current genetic background. The 18 entries of Group II also displayed good levels of resistance, but in contrast to those in

Table I. Virulence attributes of Australian cultures of Puccinia recondita f. sp. tritici used to postulate $L r$ genes in European wheats.

\begin{tabular}{|c|c|c|}
\hline Pathotype $^{a}$ & Accession Number ${ }^{b}$ & Virulence ${ }^{\mathrm{c}}$ \\
\hline $10-1,2,3,4^{\mathrm{e}}$ & 720469 & Lr1, Lr2a, Lr2c, Lr10, Lr14a, Lr15, Lr17b, Lr20, Lr23 \\
\hline $26-0^{\mathrm{d}, \mathrm{e}}$ & 640157 & $\operatorname{Lr} 2 c, \operatorname{Lr} 10, \operatorname{Lr} 17 b$ \\
\hline $53-1,(6),(7), 10,11^{\mathrm{d}, \mathrm{e}}$ & 810043 & Lr10, Lr13, Lr16, Lr20 \\
\hline $53-(6),(7), 9,10,11^{\mathrm{d}, \mathrm{e}}$ & 870115 & Lr11, Lr13, Lr16, Lr17b, Lr26 \\
\hline $64-1,3^{\mathrm{d}, \mathrm{e}}$ & 710208 & Lr1, Lr2c, Lr10, Lr14a, Lr17b, Lr20 \\
\hline $64-(6),(7),(10), 11^{\mathrm{e}}$ & 900053 & $\operatorname{Lrl}, \operatorname{LrlO}, \operatorname{Lrl6}$ \\
\hline $76-1,3,5,10^{\mathrm{d}, \mathrm{e}}$ & 890171 & Lr2c, Lr3a, Lr3bg, Lr3ka, Lr10, Lr13, Lr14a, Lr17b, Lr20 \\
\hline $104-2,3,6,(7), 9^{\mathrm{d}, \mathrm{e}}$ & 840412 & Lr1, Lr2c, Lr3a, Lr3bg, Lr10, Lr14a, Lr17b, Lr23, Lr26, Lr27+Lr31 \\
\hline $104-1,2,3,(6),(7), 9,11^{\mathrm{e}}$ & 970188 & Lr1, Lr2c, Lr3a, Lr3bg, Lr10, Lr14a, Lr16, Lr20, Lr23, Lr26 \\
\hline $122-1,2,3,(6),(7), 11^{\mathrm{d}, \mathrm{e}}$ & 910067 & Lr1, Lr2a, Lr2c, Lr3a, Lr3bg, Lr10, Lr14a, Lr16, Lr20, Lr23 \\
\hline
\end{tabular}

${ }^{a}$ See McIntosh et al. [7] for a description of pathotype designation.

${ }^{\mathrm{b}}$ Plant Breeding Institute Cobbitty accession number.

'Tested for pathogenicity on differential genotypes with the resistance genes $L r 1, L r 2 a, L r 2 c, L r 3 a, L r 3 b g, L r 3 k a, L r 9, L r 10, L r 11$, Lr13, Lr14a, Lr15, Lr16, Lr17a, Lr17b, Lr19, Lr20, Lr21, Lr23, Lr24, Lr25, Lr26, Lr27+Lr31, Lr28, Lr29, Lr30.

${ }^{\mathrm{d}}$ Used in tests of the 1997 nursery.

${ }^{\mathrm{e}}$ Used in tests of the 1999 nursery. 
Table II. Results of the multilocation test for leaf rust resistance. Field and seedling tests were performed in Europe. For field tests entries were rated as resistant (R), moderately resistant (MR), moderately susceptible (MS) or susceptible (S). For seedling tests entries were rated as resistant (R), intermediate (not shown) and susceptible (S).

\begin{tabular}{|c|c|c|c|c|c|c|c|c|c|c|c|c|c|}
\hline \multirow[t]{2}{*}{ Group } & \multirow[t]{2}{*}{ Entry } & \multirow[t]{2}{*}{ Origin } & \multirow{2}{*}{$\begin{array}{l}\text { No. of } \\
\text { years } \\
\text { tested }\end{array}$} & \multicolumn{4}{|c|}{$\begin{array}{c}\text { Field tests } \\
\text { No. of environments }\end{array}$} & \multicolumn{4}{|c|}{$\begin{array}{l}\text { Seedling tests } \\
\text { No. of }\end{array}$} & \multirow[t]{2}{*}{$\begin{array}{l}\text { Type of } \\
\text { resistance }\end{array}$} & \multirow[t]{2}{*}{$\begin{array}{l}\text { Postulated } \\
L r \text { genes }\end{array}$} \\
\hline & & & & Tested & $\mathrm{R}$ & MR & MS & $\mathrm{S}$ & tests & $\% \mathrm{R}$ & $\% \mathrm{~S}$ & & \\
\hline \multirow[t]{9}{*}{ I } & BATIS & $\mathrm{D}$ & 4 & 43 & 39 & 4 & 0 & 0 & 98 & 12 & 84 & adult & 13 \\
\hline & CAPO & A & 2 & 25 & 25 & 0 & 0 & 0 & 62 & 8 & 81 & adult & $13+$ \\
\hline & RE9001 & $\mathrm{F}$ & 2 & 24 & 23 & 1 & 0 & 0 & 60 & 22 & 63 & adult $+^{1}$ & 37 \\
\hline & RE9801 & $\mathrm{F}$ & 2 & 23 & 18 & 5 & 0 & 0 & 63 & 21 & 62 & adult+ & $37(+14 a ?)$ \\
\hline & TERZA & $\mathrm{CH}$ & 3 & 35 & 33 & 2 & 0 & 0 & 86 & 40 & 45 & seedling $+^{2}$ & $10+37$ \\
\hline & TORONIT & $\mathrm{CH}$ & 3 & 33 & 27 & 6 & 0 & 0 & 85 & 45 & 35 & seedling+ & $20+26$ \\
\hline & TITLIS & $\mathrm{CH}$ & 3 & 35 & 32 & 3 & 0 & 0 & 85 & 75 & 13 & seedling & $10+37$ \\
\hline & BARRA & I & 3 & 31 & 29 & 2 & 0 & 0 & 86 & 84 & 10 & seedling & $3 a+13+26+?$ \\
\hline & BEAUFORT & UK & 2 & 22 & 20 & 2 & 0 & 0 & 49 & 82 & 8 & seedling & $26+37$ \\
\hline \multirow[t]{18}{*}{ II } & JOSEF & A & 2 & 24 & 12 & 6 & 6 & 0 & 63 & 3 & 92 & adult & 13 \\
\hline & BONTARIS & $\mathrm{D}$ & 2 & 25 & 19 & 4 & 2 & 0 & 63 & 5 & 89 & adult & 13 \\
\hline & RENAN & $\mathrm{F}$ & 3 & 35 & 29 & 4 & 2 & 0 & 84 & 10 & 87 & adult & 37 \\
\hline & TRANSIT & $\mathrm{D}$ & 4 & 44 & 35 & 8 & 1 & 0 & 98 & 14 & 80 & adult & $13+$ \\
\hline & ESTICA & $\mathrm{F}$ & 3 & 35 & 31 & 3 & 1 & 0 & 80 & 15 & 76 & adult+ & $13+14 a+?$ \\
\hline & RE9601 & $\mathrm{F}$ & 2 & 24 & 20 & 3 & 1 & 0 & 60 & 17 & 70 & adult+ & $37(+14 a ?)$ \\
\hline & KUNSAG & $\mathrm{H}$ & 2 & 24 & 13 & 7 & 4 & 0 & 61 & 23 & 67 & adult+ & $?$ \\
\hline & P8634 & $\mathrm{A}$ & 2 & 24 & 21 & 2 & 1 & 0 & 63 & 17 & 67 & adult+ & $13+$ \\
\hline & MOB 2860/90 & $\mathrm{P}$ & 3 & 35 & 27 & 6 & 2 & 0 & 85 & 33 & 55 & adult+ & $3 a+13$ \\
\hline & KALASZ & $\mathrm{H}$ & 2 & 22 & 14 & 5 & 3 & 0 & 60 & 42 & 50 & adult+ & $13+$ \\
\hline & PANDA & $\mathrm{P}$ & 3 & 33 & 21 & 7 & 5 & 0 & 84 & 43 & 50 & adult+ & $3 a+$ \\
\hline & LONA & $\mathrm{CH}$ & 3 & 30 & 13 & 10 & 7 & 0 & 83 & 40 & 42 & adult+ & $13+20$ \\
\hline & PANDAS & I & 3 & 29 & 22 & 6 & 1 & 0 & 85 & 55 & 38 & seedling+ & $3 a+13$ \\
\hline & BRIGADIER & UK & 3 & 30 & 17 & 9 & 4 & 0 & 82 & 48 & 34 & seedling+ & $13+26+37$ \\
\hline & VICTO & $\mathrm{F}$ & 3 & 25 & 20 & 4 & 1 & 0 & 85 & 54 & 34 & seedling+ & $1+3 a+?$ \\
\hline & CHARGER & UK & 2 & 24 & 19 & 2 & 3 & 0 & 61 & 43 & 31 & seedling+ & $10+13$ \\
\hline & FIOCCO & I & 4 & 37 & 32 & 3 & 2 & 0 & 100 & 69 & 23 & seedling+ & $3 a+13+26+?$ \\
\hline & REAPER & UK & 3 & 34 & 25 & 7 & 2 & 0 & 82 & 67 & 16 & seedling+ & $10+13+$ \\
\hline \multirow[t]{7}{*}{ III } & FORNO & $\mathrm{CH}$ & 4 & 44 & 37 & 5 & 1 & 1 & 98 & 3 & 92 & adult & $14 a$ \\
\hline & WILGA & $\mathrm{P}$ & 3 & 31 & 22 & 8 & 0 & 1 & 81 & 26 & 68 & adult+ & 26 \\
\hline & RE9615 & $\mathrm{F}$ & 2 & 25 & 22 & 2 & 0 & 1 & 59 & 25 & 56 & adult+ & $13^{3}+$ \\
\hline & PEGASO & $\mathrm{I}$ & 4 & 39 & 36 & 1 & 1 & 1 & 99 & 55 & 36 & seedling+ & 10 \\
\hline & PIKO & $\mathrm{D}$ & 2 & 24 & 19 & 3 & 1 & 1 & 61 & 52 & 34 & seedling+ & $13^{3}$ \\
\hline & RAPOR & $\mathrm{F}$ & 2 & 23 & 18 & 4 & 0 & 1 & 59 & 49 & 27 & seedling+ & $13+37$ \\
\hline & TREMIE & $\mathrm{F}$ & 2 & 22 & 17 & 4 & 0 & 1 & 59 & 69 & 22 & seedling+ & $10+13$ \\
\hline \multirow[t]{9}{*}{ IV } & TAMARO & $\mathrm{CH}$ & 4 & 44 & 20 & 10 & 8 & 6 & 100 & 3 & 96 & adult/partial & $14 a$ \\
\hline & GOBE & $\mathrm{H}$ & 2 & 16 & 6 & 5 & 2 & 3 & 36 & 3 & 94 & adult/partial & not tested \\
\hline & LINDOS & $\mathrm{D}$ & 4 & 44 & 24 & 11 & 6 & 3 & 101 & 4 & 93 & adult/partial & 13 \\
\hline & RUNAL & $\mathrm{CH}$ & 4 & 44 & 14 & 12 & 7 & 11 & 98 & 4 & 93 & adult/partial & 13 \\
\hline & COMPASS & A & 2 & 22 & 13 & 3 & 4 & 2 & 63 & 3 & 90 & adult/partial & 13 \\
\hline & CAXTON & UK & 3 & 34 & 21 & 9 & 3 & 1 & 84 & 11 & 87 & adult/partial & 13 \\
\hline & P7852 & A & 2 & 24 & 13 & 6 & 4 & 1 & 62 & 11 & 82 & adult/partial & $13+$ \\
\hline & CONTRA & $\mathrm{D}$ & 4 & 40 & 20 & 11 & 6 & 3 & 97 & 15 & 81 & adult/partial & $13+17 b$ \\
\hline & ZUGOLY & $\mathrm{H}$ & 2 & 16 & 6 & 3 & 2 & 5 & 36 & 17 & 81 & adult/partial & $?$ \\
\hline
\end{tabular}


Table II. Continued.

\begin{tabular}{|c|c|c|c|c|c|c|c|c|c|c|c|c|c|}
\hline \multirow[t]{2}{*}{ Group } & \multirow[t]{2}{*}{ Entry } & \multirow[t]{2}{*}{ Origin } & \multirow{2}{*}{$\begin{array}{l}\text { No. of } \\
\text { years } \\
\text { tested }\end{array}$} & \multicolumn{4}{|c|}{$\begin{array}{c}\text { Field tests } \\
\text { No. of environments }\end{array}$} & \multicolumn{4}{|c|}{$\begin{array}{l}\text { Seedling tests } \\
\text { No. of }\end{array}$} & \multirow[t]{2}{*}{$\begin{array}{l}\text { Type of } \\
\text { resistance }\end{array}$} & \multirow[t]{2}{*}{$\begin{array}{l}\text { Postulated } \\
L r \text { genes }\end{array}$} \\
\hline & & & & Tested & $R$ & MR & MS & $\mathrm{S}$ & tests & $\% \mathrm{R}$ & $\% \mathrm{~S}$ & & \\
\hline \multirow{23}{*}{$\begin{array}{l}\text { IV } \\
\text { (cont.) }\end{array}$} & AZTEC & $\mathrm{F}$ & 3 & 32 & 17 & 9 & 5 & 1 & 84 & 12 & 80 & adult/partial & 13 \\
\hline & MIKON & $\mathrm{D}$ & 2 & 24 & 14 & 4 & 4 & 2 & 59 & 19 & 80 & adult/partial & $3 a+13$ \\
\hline & GARABOLY & $\mathrm{H}$ & 2 & 16 & 8 & 3 & 3 & 2 & 37 & 19 & 78 & adult+/partial & $?$ \\
\hline & PINKA & $\mathrm{H}$ & 2 & 18 & 8 & 4 & 2 & 4 & 60 & 20 & 75 & adult+/partial & $3 a+?$ \\
\hline & VIGINTA & $\mathrm{CZ}$ & 4 & 40 & 15 & 13 & 4 & 8 & 97 & 20 & 73 & adult+/partial & $3 a$ \\
\hline & ALIDOS & $\mathrm{D}$ & 4 & 44 & 22 & 8 & 9 & 5 & 97 & 18 & 72 & adult+/partial & $14 a$ \\
\hline & STH89 & $\mathrm{P}$ & 3 & 35 & 24 & 5 & 3 & 3 & 86 & 24 & 69 & adult+/partial & $3 a+13$ \\
\hline & CHD236/90 & $\mathrm{P}$ & 2 & 24 & 19 & 2 & 1 & 2 & 60 & 25 & 65 & adult+/partial & $13+26^{3}$ \\
\hline & RE8714 & $\mathrm{F}$ & 2 & 24 & 21 & 0 & 2 & 1 & 55 & 24 & 56 & adult+/partial & $3 a+13+37$ \\
\hline & KENDE & $\mathrm{H}$ & 2 & 24 & 8 & 5 & 3 & 8 & 57 & 39 & 54 & adult+/partial & $3 a$ \\
\hline & DAVID & $\mathrm{H}$ & 2 & 16 & 8 & 4 & 0 & 4 & 36 & 36 & 53 & adult+/partial & $?$ \\
\hline & SMH4070 & $\mathrm{P}$ & 3 & 35 & 23 & 7 & 4 & 1 & 86 & 42 & 52 & adult+/partial & $1^{3}$ \\
\hline & VLADA & $\mathrm{CZ}$ & 3 & 34 & 13 & 7 & 1 & 3 & 86 & 49 & 40 & seedl.+/partial & $1+3 a+13$ \\
\hline & SIRIA & $\mathrm{CZ}$ & 3 & 34 & 13 & 10 & 8 & 3 & 85 & 44 & 35 & seedl.+/partial & $10+13$ \\
\hline & HEREWARD & UK & 4 & 44 & 30 & 7 & 3 & 4 & 94 & 41 & 31 & seedl.+/partial & $10+13$ \\
\hline & ORTOP & $\mathrm{F}$ & 2 & 25 & 17 & 5 & 1 & 2 & 63 & 43 & 33 & seedl.+/partial & $10+13$ \\
\hline & DANIS & $\mathrm{CH}$ & 4 & 44 & 26 & 7 & 6 & 5 & 99 & 49 & 28 & seedl.+/partial & $10+13$ \\
\hline & TALTOS & $\mathrm{H}$ & 2 & 18 & 9 & 7 & 1 & 1 & 37 & 51 & 35 & seedl.+/partial & $3 a+26$ \\
\hline & BLAVA & $\mathrm{CZ}$ & 3 & 31 & 24 & 4 & 2 & 1 & 86 & 52 & 34 & seedl.+/partial & $3 k a$ \\
\hline & SMH2788 & $\mathrm{P}$ & 2 & 24 & 15 & 4 & 1 & 4 & 63 & 56 & 35 & seedl.+/partial & 1 \\
\hline & REPCE & $\mathrm{H}$ & 2 & 24 & 12 & 4 & 4 & 4 & 62 & 58 & 27 & seedl.+/partial & $1+3 a$ \\
\hline & BOVAL & $\mathrm{CH}$ & 4 & 44 & 27 & 10 & 4 & 3 & 97 & 65 & 20 & seedl.+/partial & $10+13+14 a$ \\
\hline & RIALTO & UK & 2 & 24 & 12 & 3 & 6 & 3 & 61 & 72 & 20 & seedl.+/partial & $10+13+26$ \\
\hline \multirow[t]{5}{*}{$\mathrm{V}$} & SPARTA & $\mathrm{CZ}$ & 3 & 31 & 5 & 2 & 5 & 19 & 86 & 49 & 48 & seedling/susc. & $3 a+13+26$ \\
\hline & BOKA & $\mathrm{CZ}$ & 3 & 34 & 8 & 9 & 8 & 9 & 82 & 2 & 93 & partial/susc. & 13 \\
\hline & BORENOS & $\mathrm{D}$ & 3 & 35 & 5 & 4 & 6 & 20 & 86 & 5 & 94 & partial/susc. & $13+$ \\
\hline & KONTRAST & $\mathrm{D}$ & 4 & 44 & 8 & 7 & 14 & 15 & 99 & 4 & 95 & partial/susc. & None \\
\hline & ALCEDO & $\mathrm{D}$ & 3 & 35 & 3 & 2 & 9 & 21 & 83 & 0 & 99 & partial/susc. & None \\
\hline VI & ARINA (susc) & $\mathrm{CH}$ & 4 & 44 & 1 & 0 & 2 & 41 & 100 & 9 & 90 & susceptible & 13? \\
\hline
\end{tabular}

${ }^{1}$ adult+: Adult plant resistance acting together with seedling resistance.

${ }^{2}$ seedling+: Seedling resistance acting together with adult plant resistance.

${ }^{3}$ heterogeneity within cultivar for the presence/absence of gene.

Group I, they were rated as MS in one to seven environments. The seven entries of Group III were rated as MS or S in one or two environments only, both of which were characterised by an exceptionally high disease pressure. We therefore concluded that the Group III genotypes also possess valuable levels of resistance. The largest group, with 32 entries, was Group IV, which included entries that were rated as $\mathrm{R}$ in most environments, but which were classified as $\mathrm{S}$ or MS in several environments. The susceptibility of these lines in some environments may be due to the occurrence of virulent pathotypes, the presence of true partial resistance which is poorly expressed under high disease pressure, or the presence of resistance which is expressed only under certain environmental conditions. Group V comprised five entries that were predominantly MS or S. The resistance of these 
entries seems to be of limited value. The variety Arina (Group VI) was included in all experiments as a common susceptible check.

\subsection{Seedling reaction in European tests}

The results of seedling tests with representative European pathotypes were used to classify the resistance of entries which displayed resistance in the field as either predominantly APR (susceptible in more than $80 \%$ of seedling tests) or predominantly seedling resistance (resistant in more that $75 \%$ of seedling tests). In most cases the classification showed that seedling and adult plant resistance acted together. In some cases there was evidence of a quantitative expression of resistance in the field, suggesting the presence of partial resistance. However, further tests are needed to verify this.

Using these criteria, Batis, Capo, Josef, Bontaris, Renan and Transit (Groups I and II), and Forno (Group III) had high levels of APR. In Group I Titlis, Barra and Beaufort had strong seedling resistance whereas other entries seemed to combine seedling and adult plant resistance.

\subsection{Presence of specific resistance genes}

Forty two of the 72 genotypes (58\%) possess the gene $\operatorname{Lrl3}$ alone or in combination with other seedling genes. The high incidence of this gene in the entries submitted to the multilocation test suggests that this gene may provide some protection against leaf rust. However, this clearly does not apply to all $\mathrm{Lr} 13$ genotypes, as some developed significant levels of leaf rust. For example, Batis (Lr13) was resistant in all field tests, whereas Josef was rated as S or MS at $25 \%$ of the locations. Similar observations were made for other genotypes, including Lindos, Runal, Compass, Boka and Borenos, with the latter two cultivars rating as $\mathrm{S}$ at $50-74 \%$ of locations. In addition, seedling tests conducted in Australia suggested the presence of Lr13 in Arina, the fully susceptible check cultivar that was susceptible at $98 \%$ of the locations tested. If Arina does indeed carry Lr13, virulence for this gene must be widespread in Europe. Results from tests in France have indicated the presence of virulence for Lr13, but do not support the presence of Lrl3 in Arina (Goyeau, unpublished data). The different field disease responses observed for cultivars with $\operatorname{Lr} 13$ in the present study suggest that either the frequency of virulence for $\mathrm{Lrl3}$ varies across Europe, and/or that additional genes (possibly unidentified APR genes or quantitative trait loci, QTL) are present in the cultivars which displayed higher resistance in the field. For these reasons the field resistance stated for $\operatorname{Lr} 13$ should be questioned and intensive research work is needed to find a meaningful explanation. Our hypothesis is that $\mathrm{Lr} 13$ is a gene with low effectiveness in both seedling and adult stages. In Australia, the occurrence of a new pathotype with virulence for Lrl3 resulted in severe rusting of cultivars such as Sunstar, which were protected only by $\operatorname{Lr} 13$ [12]. The gene is still nonetheless important since it has in combination with other genes continued to provide protection against most pathotypes. More recently, several long season winter wheats with $\mathrm{Lrl3}$ and $\mathrm{Lr} 17 \mathrm{~b}$ have developed high levels of leaf rust in Australia due to the occurrence of two new pathotypes which combine virulence for both of these genes (Park, unpublished). Interestingly, both $\mathrm{Lr} 13$ virulent pathotypes are avirulent on the Thatcher isogenic line carrying $\operatorname{Lr} 13$, because they are avirulent for $L r 22 b$, an APR gene present in Thatcher and hence also present in all of the Thatcher NIL series (except presumably Thatcher+Lr22a) [11]. The good field resistance of Thatcher+Lr13 in some European regions reported by Mesterhazy et al. [8] may also be due to the effect of $\operatorname{Lr} 22 b$.

Another gene which confers APR is Lr37 [2]. This gene originated from Aegilops ventricosa, and is linked to resistances for stem rust, stripe rust and eyespot or strawbreaker disease (caused by Pseudocercosporella herpotrichoides) [3]. The resistance was first deployed in several French wheats and later in cultivars from other European countries. Nine cultivars with $L r 37$ were identified amongst the nursery entries, and in all but two of these, other gene(s) were detected. Hence, it is difficult to assess the effectiveness of this gene alone to current leaf rust pathotypes in Europe. The line RE9001 and Renan appeared to carry Lr37 alone, 
where it provided low resistance in seedling and full resistance in adult stage. Several Australian wheat cultivars with $L r 37$ alone also display high levels of resistance under field conditions [7]. The significance of the differences observed in the response of entries with $L r 37$ either singly or in combination with other genes is difficult to assess, but may relate to differences in ratings between cooperators, differences in environmental conditions between field sites, and/or the presence of additional resistance genes. Virulence for $\operatorname{Lr} 37$ has not been recorded in Europe to date.

It is clear that APR is common in many of the cultivars investigated (Tab. II), particularly in cases where seedlings were mostly susceptible and adult plants mostly resistant. Using these criteria, 40 of the 72 cultivars were classified as having APR. As already discussed, the genetic basis of this resistance is not clear, particularly because of the doubts concerning the effectiveness of Lr13. In many cases, it is suspected that QTL may contribute to the resistance observed. Another gene that could be present in the entries tested is Lr34. The gene Lr34 is thought to be present in many wheat cultivars, including some produced by CIMMYT [4], in South America [1], Australia [7], China [17], and India [9]. The pedigrees of many wheats reported as carrying this gene can be traced back to Frontana and other wheats from South America, which in turn may have resulted from the use of Chinese Spring, also regarded as having Lr34, by South American breeders [4]. The occurrence of Lr34 in European wheats is less clear. It is believed that Lr34 is present in Bezostaja 1 [7], and so it is possible that derivatives of this cultivar could carry this gene. Manninger [6] concluded that $\operatorname{Lr} 34$ was common in a collection of Hungarian wheat cultivars. Further work is needed to gain a better understanding of the possibile distribution of this gene in European wheats.

The existence of partial resistance in the cultivars tested is difficult to assess on the basis of the data collected and tests as suggested by Rubiales and Niks [16] are needed to examine this in greater detail. The cultivar Alcedo is of interest for such tests as it lacked detectable seedling resistance genes in tests conducted in both Australia and
Europe, but possessed some resistance at some field sites.

The results obtained from the present study allow several conclusions to be made. It would seem unlikely that the common occurrence of Lrl3 and several uncharacterized resistance genes is due to chance. There is evidence that the uncharacterized resistance genes play a significant role and therefore more research is needed to characterise them genetically. We are convinced that leaf rust research needs to pay more attention to APR, as suggested by Knott [5] for stem rust research. Increased effort in understanding resistance to leaf rust in European wheats will provide a stronger basis for breeding cultivars with higher and more durable resistance. The present study has also shown that not all gene combinations are successful, and so care is needed if attempts are to be made to pyramid resistance genes in new cultivars. CIMMYT, Mexico has undertaken research in recent years to target partial resistance to leaf rust, and further research on partial resistance in European wheats might also have greater significance in the future. Considerable experience in working with partial resistance to rusts in cereals already exists in European laboratories [16].

Finally, many European wheat breeders do not have the direct support of rust resistance genetics programs, rust screening facilities and research aimed at monitoring pathogenic variability in the pathogen population. Future attempts to incorporate resistance to leaf rust into European wheat cultivars would benefit greatly from increased efforts in these areas, and from an integration of these activities into the breeding programs.

Acknowledgements: The authors acknowledge the support by the COST Action 817, which enabled the extensive network of cereal workers to meet and exchange ideas and to organize the multilocation test reported in the present paper. We are very grateful for the inspiring and effective leadership by Chairperson Hanne Østergård in this Action.

\section{Appendix}

Pavel BARTOS: Research Institute of Crop Production, 16106 Praha-Ruzyne, Czech Republic 
Maria Csösz: Cereal Research Non-profit Co., PO Box 391, 6701 Szeged, Hungary

Henriette GoYEAU: INRA, Laboratoire Pathologie Végétale, 78850 Thiverval Grignon, France

Mariana ITTU: Research Institute for Cereals and Industrial Crops (ICCPT), 8264 Fundulea, Romania

Elwyn JONES: Institute of Grassland and Environmental Research, Aberystwith, Dyfed SY23 3EB, UK

Franziska LösCHENBERGER: Probstdorfer Saatzucht GmbH, 2301 Probstdorf, Austria

Klara MANNINGER: Plant Protection Institute, Hungarian Academy of Sciences, 1525 Budapest, Hungary

Marina PASQUINI: Experimental Institute for Cereal Research, 00191 Roma, Italy

Klaus RICHTER: Saatzucht Hadmersleben GmbH, 39398 Hadmersleben, Germany

Diego Rubiales: Instituto de Agricultura Sostenible (CSIC), 14080 Córdoba, Spain

Gabriele SchACHERMAYR: Swiss Federal Research Station for Agroecology and Agriculture FAL, 8046 Zürich, Switzerland

Anna Strzembicka: Plant Breeding and Acclimatization Institute, 30-423 Krakow, Poland

Maxime Trottet: INRA-Rennes, Station d'Amélioration des Plantes, 35653 LeRheu Cedex, France

Otto Unger: Nordsaat Saatzucht GmbH, 38895 Böhnhausen, Germany

Gyula VIDA: Agricultural Research Institute of the Hungarian Academy of Science, 2462 Martonvásár, Hungary

Ursula WALTHER: Bundesanstalt für Züchtungsforschung BAZ, 06435 Aschersleben, Germany

\section{References}

[1] Barcellos A.L., Roelfs A.P., Moraes-Fernandes M.I.B. de, Inheritance of adult plant leaf rust resistance in the Brazilian wheat cultivar Toropi, Plant Dis. 84 (2000) 90-93.

[2] Bariana H.S., McIntosh R.A., Cytogenetic studies in wheat. XV. Location of rust resistance genes in VPM1 and their genetic linkage with other disease resistance genes in chromosome 2A, Genome 36 (1993) 476-482.

[3] Doussinault G., Dosba F., Tanguy A.M., Analyse monosomique de la résistance à la rouille jaune du géniteur blé tendre VPM1, Académie d'Agriculture de France, Extrait du procès-verbal de la Séance du 14 janvier 1981, 1981, pp. 133-138.
[4] Dyck P.L., Genetics of adult-plant leaf rust resistance in 'Chinese Spring' and 'Sturdy' wheats, Crop Sci. 31 (1991) 309-311.

[5] Knott D.R., The Wheat Rusts: Breeding for Resistance, Springer-Verlag, Berlin, 1989.

[6] Manninger K., Genes of rust resistance in Hungarian wheat cultivars, Beiträge zur Züchtungsforschung - Bundesanstalt für Züchtungsforschung an Kulturpflanzen 4 (1998) 13-14.

[7] McIntosh R.A., Wellings C.R., Park R.F., Wheat Rusts: An atlas of resistance genes, CSIRO Publications, East Melbourne, ISBN 0-7923-3430-2, 1995.

[8] Mesterházy Á., Bartos P., Goyeau H., Niks R.E., Csösz M., Andersen O., Casulli F., Ittu M., Jones E., Manisterski J., Manninger K., Pasquini M., Rubiales D., Schachermayr G., Strzembicka A., Szunics L., Todorova M., Unger O., Vanco B., Vida G., Walther U., European virulence survey for leaf rust in wheat, Agronomie 20 (2000) 793-804.

[9] Nayar S.K., Bhardwaj S.C., Prashar M., Characterization of $\mathrm{Lr} 34$ and $\mathrm{Sr} 2$ in Indian wheat (Triticum aestivum) germplasm, Indian J. Agric. Sci. 69 (1999) 718-721.

[10] Park R.F., Felsenstein F.G., Physiological specialization and pathotype distribution of Puccinia recondita f. sp. tritici in western Europe 1995, Plant Pathol. 47 (1998) 157-164.

[11] Park R.F., McIntosh R.A., Adult plant resistances to Puccinia recondita f. sp. tritici in wheat, N.Z. J. Crop Hortic. Sci. 22 (1994) 151-158.

[12] Park R.F., Wellings C.R., Pathogenic specialization of wheat rusts in Australia and New Zealand in 1988 and 1989, Australas. Plant Pathol. 21 (1992) 61-69.

[13] Park R.F., Burdon J.J., McIntosh R.A., Studies on the origin, spread, and evolution of an important group of Puccinia recondita f. sp. tritici pathotypes in Australasia, Eur. J. Plant Pathol. 101 (1995) 613-622.

[14] Parlevliet J.E., Components of resistance that reduce the rate of epidemic development, Ann. Rev. Phytopathol. 17 (1979) 203-222.

[15] Roelfs A.P., Resistance to leaf and stem rust in wheat, in: Breeding strategies for resistance to the rusts of wheat, CIMMYT, Mexico, D.F., 1988, pp. 10-22.

[16] Rubiales D., Niks R.E., Characterization of Lr34, a major gene conferring nonhypersensitive resistance to wheat leaf rust, Plant Dis. 79 (1995) 1208-1212. 
[17] Singh R.P., Chen W.Q., He Z.H., Leaf rust resistance of spring, facultative and winter wheat cultivars from China, Plant Dis. 83 (1999) 644-651.

[18] Stakman E.C., Steward D.M., Loegering W.Q., Identification of physiological races of Puccinia graminis var. tritici, US Dept. Agric. Bull. ARS E617, 1962.
[19] Winzeler M., Winzeler H., Keller B., Streckeisen Ph., Hitz S., Messmer M., Schachermayr G., Feuillet C., Strategien der Züchtung auf Braunrostresistenz bei Weizen, Bericht 46. Arbeitstagung der Arbeitsgemeinschaft der Saatzuchtleiter, Vereinigung österreichischer Pflanzenzüchter, BAL Gumpenstein, 1995, pp. 83-88.

To access this journal online: www.edpsciences.org 